\title{
Performance of solar dish Stirling engine systems under Egyptian operating conditions
}

\author{
${ }^{1}$ Ahmed M. Assal, ${ }^{2}$ Mostafa R. A. Atia, ${ }^{3}$ S Shaaban \\ ${ }^{1}$ Heliopolis University for sustainable development (HU), Faculty of \\ Engineering, Cairo \\ 23 Arab Academy for Science, Technology and Maritime Transport \\ (AASTMT), Faculty of Engineering, Cairo \\ emails: ${ }^{1}$ ahmed.assal@hu.edu.eg, ${ }^{2}$ mrostom1@aast.edu, \\ 3 sameh.shaaban@aast.edu
}

\begin{abstract}
Egypt's demand for electricity is rapidly growing, and it is becoming more urgent to develop alternative power resources to meet its own energy needs. Over recent years, development of renewable energy has become a priority for Egypt. Due to its geographical location and climate, Egypt has an average level of solar radiation between 2,000 to 3,200 $\mathrm{kWh} / \mathrm{m}^{2}$ per year. As a result, Egypt has a significant potential for the development of solar energy application. The solar dish Stirling (DS) system performance is dependent on the solar data of the location. Several studies investigated the performance of the system in different locations around the world. The objective of this study is to develop a comprehensive simulation model for the solar dish Stirling engine system. The model is used to investigate the system performance under Egyptian operating conditions. The results of 21 different zones that cover most of the Egyptian regions are calculated and compared to determine the overall performance of the system and to determine the suitable locations for project development. Results showed a yearly average power output from the simulated $6.6 \mathrm{~m}$ aperture diameter system that ranges from 5800W in El-Natroon area to $7100 \mathrm{~W}$ in Aswan. A comparison between the simulated DS system model and an equivalent PV system shows that the DS system requires $37.6 \%$ less land to generate the same amount of power. Moreover, the DS system gives higher overall system efficiency than the equivalent PV system considering the shading that affects the area of land needed for the system. The results show that using the dish Stirling engine (DS) systems in Egypt will result in acceptable performance in terms of power output and efficiency.
\end{abstract}

\section{Keywords}

Solar dish Stirling engine systems, Solar energy, Concentrated solar power, CSP, Energy, Simulation, Stirling engine, Performance investigation. 


\section{Nomenclature}

\section{List of symbols}

$\theta \quad$ Crank angle (Radians)

A Area (m)

$\theta_{i} \quad$ Incident angle (Radians)

$\mathrm{c}_{\mathrm{p}} \quad$ Specific heat at constant pressure $\rho_{\text {con }}$

Concentrator reflectance $(\mathrm{J} / \mathrm{kg} . \mathrm{K})$

$\mathrm{c}_{\mathrm{v}} \quad$ Specific heat at constant Volume $\sigma$

Stefan Boltzmann's constant (J/kg.K)

d Derivative with respect to crank $\tau$ Transmittance angle

DNI Direct normal irradiance $\left(\mathrm{W} / \mathrm{m}^{2}\right) \quad \varphi_{\text {rec }}$ Capture fraction

E Unshaded concentrator fraction

h Convective coefficient $\left(\mathrm{W} / \mathrm{m}^{2} . \mathrm{K}\right)$

\section{List of suffixes}

$\mathrm{k} \quad$ Thermal conductivity (W/m.K) ap

$\mathrm{L} \quad$ Thickness of insulation (m) c

$\dot{m} \quad$ Mass flow rate $(\mathrm{kg} / \mathrm{s}) \quad$ cav

M Total mass of working gas $(\mathrm{kg})$

$\mathrm{p} \quad$ Pressure $(\mathrm{Pa})$

Q Heat energy $(\mathrm{J})$

amb Ambient

ap Receiver aperture

c Compression space

cav Receiver cavity

con Concentrator

cond Conduction

conv Convection

$\dot{Q} \quad$ Heat rate $(\mathrm{W})$

e Expansion space

$\mathrm{R} \quad$ Gas constant $(\mathrm{J} / \mathrm{mol} . \mathrm{K})$

$\mathrm{R}_{\mathrm{th}} \quad$ Thermal resistance

forced Forced convection

h Heater

int Intercepted

$\mathrm{T} \quad$ Temperature $(\mathrm{K})$

$\mathrm{V} \quad$ Volume $\left(\mathrm{m}^{3}\right)$

W Work (J)

k Cooler

loss Losses

\section{List of Greek symbols}

$\alpha \quad$ Phase angle advance (Radians)

$\begin{array}{ll}\text { natura } & \text { Natural convection } \\ 1 & \\ \mathrm{r} & \text { Regenerator } \\ \mathrm{rad} & \text { Radiation } \\ \mathrm{rec} & \text { Receiver } \\ \mathrm{sw} & \text { Swept volume } \\ \text { total } & \text { Total convection } \\ \mathrm{w} & \text { Wall }\end{array}$

$\alpha_{\text {eff }}$ Effective absorptance

$\alpha_{\text {rec }}$ Receiver absorptance

$\varepsilon \quad$ Effectiveness

$\varepsilon_{\text {cav }}$ Cavity effective emissivity

$\varepsilon_{r} \quad$ Regenerator effectiveness

$\eta \quad$ Efficiency

\section{Introduction}

Human civilization and standards of living are very dependent on energy, which is needed for lighting, cooking, transportation, communication, production, and many other uses. Without energy, the standards of living will be affected, and civilization will collapse (Johnson, 2018).

Conventional energy sources based on fossil fuel such as coal, oil, and natural gas are badly affecting the environment, human life, and economic progress. Another 
problem of the mass usage of fossil fuel is the emission of greenhouse gases and the depletion of the energy resources. Those setbacks are enough reasons to use renewable energy sources like wind energy, hydroelectric, biomass, geothermal, tidal, and solar energy. This study focuses on the studying of a solar energy technology named concentrated solar power (CSP) (Akella, Saini, \& Sharma, 2009).

CSP technology uses mirrors to reflect and concentrate sunlight into a single point called the focal point where it is collected and converted into heat power. CSP systems are generally used for utility-scale projects. Moreover, there are varieties of CSP systems such as parabolic trough systems, solar power towers, and dish Stirling engine (DS) systems which is the scope of this research (Lovegrove \& Stein, 2012). The DS system concentrates the Direct Normal Irradiance (DNI) from the sun to operate a Stirling engine, which in turns drives an electric generator that produces electricity.

A detailed summary of every component in the dish Stirling engine system including the system description, types, numerical models, sizing, and data on existing projects can be found in (William B. Stine and Richard B. Diver, 1994). These models are used to achieve a method for integration of the component models to form a comprehensive model. The thermal, electrical, and control systems of the dishStirling system are presented in (Howard \& Harley, 2010), along with a method for simulation based on (Urieli \& Berchowitz, 1984). Typical results are provided for the instantaneous working gas pressure, torque, and temperature. The results indicated how these parameters vary with solar DNI in steady state. Simulation of a gridconnected dish Stirling solar power plant was published in (Howard, Harley, \& Venayagamoorthy, 2010).

(Mancini et al., 2003) reviewed the status of DS systems that are being developed for commercial markets and presented system specifications and reviewed system performance and cost data. (Reinalter et al., 2008) studied the detailed performance of the $10 \mathrm{~kW}$ CNRS-Promes EuroDish unit, calculating the thermal losses and performance of every component of the system. (Mancini et al., 2003) Studied the same system but in different locations in India and Italy. (Fraser \& Klein, 2008) studied the model of every component individually, and then performed a case study on the overall performance of the system and compared the results with three years of data from the Wilkinson, Goldberg, and Associates, Inc. (WGA) Mod 2-2 system.

(Nepveu, Ferriere, \& Bataille, 2009) presented a thermal model of the energy conversion of the $10 \mathrm{~kW}_{\mathrm{el}}$ EuroDish Stirling unit erected at the CNRS-Promes laboratory in Odeillo and made a thermodynamic analysis of the SOLO 161 Stirling engine. (Rogdakis, Antonakos, \& Koronaki, 2012) conducted a special thermodynamic analysis of the engine performance of a Solo Stirling Engine V161 cogeneration module installed in Athens. (Bataineh \& Taamneh, 2017) investigated the performance of standalone solar Stirling dish system used to electrify rural houses using SAM software. 
(Shazly, Hafez, El-Shenawy, \& Eteiba, 2014) presented the modeling and simulation for a solar-powered Stirling engine working at low-temperature range using MATLAB. (Mansiri, Sukchai, \& Sirisamphanwong, 2014) studied the possibilities of generating electricity by using a small scale solar dish Stirling engine system in Thailand using existing models and validated the results using experimental data. (Praene, Radanielina, \& To, 2015) used MATLAB to generate a theoretical model to investigate the energy efficiency variation of the system for eight main sites in Madagascar.

Studying this system requires an in-depth understanding of each of its components. The DS system consists of main components like the solar tracking system, the paraboloid dish concentrator, the solar receiver, the Stirling engine, and the electric generator. The system also has some other components like the control unit and the cooling system.

The solar tracking system is a mechanism that directs the structure of the system towards the sun during operating hours. A detailed review of the different types of tracking mechanisms and the applications for every type can be found in (Racharla \& Rajan, 2017).

The solar concentrator is usually a paraboloid dish that concentrates DNI into a focal point. Studying solar concentrators requires the knowledge of the different types of concentrators (Rabl, 1976), their optical (Saša Pavlović, Velimir Stefanović, Darko Vasiljević, \& Emina Petrović, 2015), geometrical (Yan, Peng, Cheng, Liu, \& Tang, 2017), and thermal analysis (Gholamalizadeh \& Chung, 2017b). (Hafez, Soliman, ElMetwally, \& Ismail, 2016) studied the effect of solar dish design features and factors such as the material and the shape of the reflector concentrators, solar radiation at the concentrator, the geometry of the concentrator including diameter, aperture area, focal Length of the paraboloid dish, the focal area diameter. Case studies for designing a paraboloid dish concentrator for certain systems can be found in (Gholamalizadeh \& Chung, 2017a) and (Alarcón, Hortúa, \& G, 2013).

Solar receivers aim to transfer the concentrated DNI to operate the Stirling engine. Receivers have many shapes, types, and applications (Kalogirou, 2004). The most commonly used receiver types in DS systems are cavity receivers and reflux receivers. (Fraser \& Klein, 2008) and (Nepveu et al., 2009) studied the receiver geometry, losses, and the effect of the intercept factor on the amount of energy transferred to the Stirling engine. (Beltran, Velazquez, Espericueta, Sauceda, \& Perez, 2012) proposed a procedure and a graphical method for designing dish/cavity systems and choosing the best materials and geometry(Reinalter et al., 2008) studied the concentrated solar flux distribution on the absorber material and the effect on its performance. (Karimi, Gheinani, \& Madadi Avargani, 2018) studied the thermal performance of solar cavity receivers in a solar paraboloid dish collector using a detailed mathematical model.

Stirling engine is the component that differentiates DS systems from other CSP systems. The Stirling engine aims to convert the heat energy coming from the receiver 
into thermal and mechanical power to operate the generator. Stirling engine has different types, configurations, driving mechanisms, and applications (Kongtragool $\&$ Wongwises, 2003) and (Egas \& Clucas, 2018). Information about different types of thermodynamic and calculation methods can be found in (Wagner, 2008) and (Ahmadi, Ahmadi, \& Pourfayaz, 2017). (Berchowitz, 2016) presented a representation of the Stirling cycle process that includes both thermodynamic processes and mechanical dynamics, resulting in a useful guide to the understanding of these machines.

(Urieli \& Berchowitz, 1984) published a complete and very reliable model that describes the performance of the Stirling engines, their work is widely used by the researchers in studying the behavior of different Stirling engines. This model consists of ideal isothermal analysis, Ideal adiabatic analysis, and non-ideal analysis of the Stirling engine. (Tlili, Timoumi, \& Nasrallah, 2008) also established a model of an irreversible cycle of the Stirling heat engine, using air as the working substance.

(Timoumi, Tlili, \& Ben Nasrallah, 2008) studied the performance optimization of Stirling engines, and published a case study on the GPU3 Stirling engines. (Tlili \& Musmar, 2013) performed a thermodynamic evaluation of a second order simulation of a Yoke Ross Stirling engine. (A. C. M. Ferreira, Teixeira, Martins, \& Nunes, 2014) conducted a study on the thermodynamic analysis using mathematical models based on the ideal adiabatic analysis of (Urieli \& Berchowitz, 1984). The author also studied the economic model of the system. (Alexakis, 2013) used advanced CFD methodologies for the performance characterization of solar Stirling engines with complex geometrical topologies.

(Rogdakis et al., 2012) investigated the performance of the SOLO V161 alpha type Stirling engine with experimental data and thermodynamic models. (Çinar, 2007) described and analyzed a variable phase angle alpha-type Stirling engine from the kinematic and thermodynamic point of view using a FORTRAN code. (Alaraby et al., 2018) studied the thermal and mechanical performance of a beta-type Stirling engine using a Stirling engine simulation scheme under MATLAB/SIMULINK.

The electric generator is the component that translates the output power of the Stirling engine into electrical power. A review of the types of electrical generators used in the dish Stirling engine systems can be found in (Mancini et al., 2003).

(Larchet et al., 2017) compared between the Levelized Cost of Electricity (LCOE) of different dish Stirling engine systems and other solar technologies such as Solar PV, parabolic trough systems, and central receiver systems in Morocco. Results showed that the LCOE in terms of \$/MWh of the dish Stirling engine systems is double that of the PV system.

It can be concluded from the reviewed literature that the DS system performance is dependent on the solar properties of the location. Egypt is considered to have good solar properties compared to other regions around the world. The problem is that the 
current studies do not give enough information about the system performance in Egypt. As a result, there are no current DS projects in Egypt.

The aim of this study is to investigate the performance of the DS systems under Egyptian operating conditions by generating a comprehensive simulation model for the system. The simulation is performed for several zones in Egypt. Finally, the results are analyzed to investigate the performance of the system in Egypt.

The methodology used in this study is covered in the next sections. an overview of the system components is presented in section 2 of this paper. The system component models are discussed in section 3. The simulation strategy and the parameters of the studied system components are presented in section 4. Simulation results are presented in section 5. Finally, the conclusion is presented in section 6 .

\section{System overview}

The DS system generally consists of a structure with a solar tracking system that holds a large paraboloid dish which reflects the irradiance coming from the sun into a cavity receiver. The receiver delivers the concentrated sunlight into the Stirling engine. The Stirling engine generates thermal and mechanical power that operate an electric generator to produce electricity. Description of the main system components is presented in this section. Figure 1 shows a diagram of the DS system components.

\subsection{Solar tracking system}

The aim of the tracking system is to allow the DS system to follow the sun throughout the day to collect as much solar energy as possible. Examples of types of tracking systems include Azimuth-elevation tracking systems and polar tracking systems. It is assumed that the angle of incidence is equal to zero for paraboloid dishes, this means that the system has perfect tracking assumption (Shazly et al., 2014).

\subsection{Paraboloid dish solar concentrator}

For the typical DS systems, concentrators are large paraboloid mirrors with a structure and a tracking system to focus the sun rays on the receiver that delivers the concentrated energy to the hot side of the engine. The reflective mirrors are mounted on a paraboloid-shaped structure. The concentrators may consist of a different number of segments of a reflective material, or a reflective sheet stretched on the paraboloid shaped structure. Solar concentrators must have a reasonable weight, durability against moisture, dust, and temperature changes, hardness against deflection and wind load, long lifetime, and must be cost-effective (William B. Stine and Richard B. Diver, 1994). 


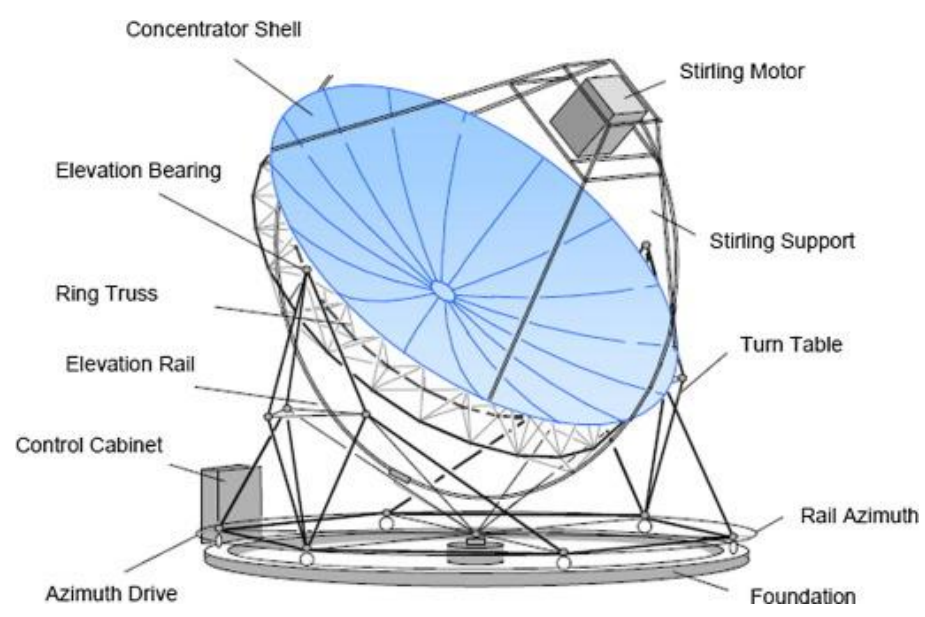

Figure 1 Solar Dish Stirling engine system components (Hafez et al., 2016)

\subsection{Receiver}

The aim of the Stirling dish receiver is to absorb thermal energy concentrated by the paraboloid dish concentrator and transfer it to the working gas flowing in the Stirling engine. The receiver must accommodate a large thermal input and solar flux with a value of over a thousand times greater than the direct solar radiation from the sun (Fraser \& Klein, 2008). The solar receiver used in the dish Stirling engine systems consists of an aperture and an absorber. The aperture is located at the position of the focal point of the concentrator to reduce the convection and radiation losses. Typical theoretical systems have concentration ratios of over 13,000. Typical aperture has a range of diameters ranging from 14 to $20 \mathrm{~cm}$ because it has to intercept a large fraction of the concentrated solar energy (Mancini et al., 2003). The intercept factor is one major parameter in the design of the solar receivers. It is the fraction of energy that enters the aperture area from the collector, which is not blocked by the receiver body. Intercept factor usually ranges between 94 and 99 percent (Fraser \& Klein, 2008).

Absorbers are typically direct illumination receivers (DIR), although some heat pipe absorbers are available. Volumetric receivers are also used in hybrid dish Stirling systems that use natural gas to supply the solar energy in shady days.

\subsection{Stirling engine}

The Stirling engine was invented by Robert Stirling in 1816. His intention was to develop an alternative for steam engines because they were not safe because of the risk of the explosion of their boilers. The Stirling engine converts heat into mechanical energy by compression and expansion of a defined quantity of a working gas usually hydrogen, helium, or air between a hot and a cold sink (Urieli \& Berchowitz, 1984).

The main mechanical Stirling engine configurations are divided into three main types known as Alpha, Beta, and Gamma arrangements. Alpha-type Stirling engines have two separate cylinders that are connected in series by a heater, regenerator, and cooler. Beta-type and Gamma-type both use displacer-piston arrangements as shown in Figure 2. Gamma-type differs from Beta-type by having the displacer and the piston 
in an in-line cylinder system, while the Gamma-type uses separate cylinders (A. C. M. Ferreira et al., 2014).

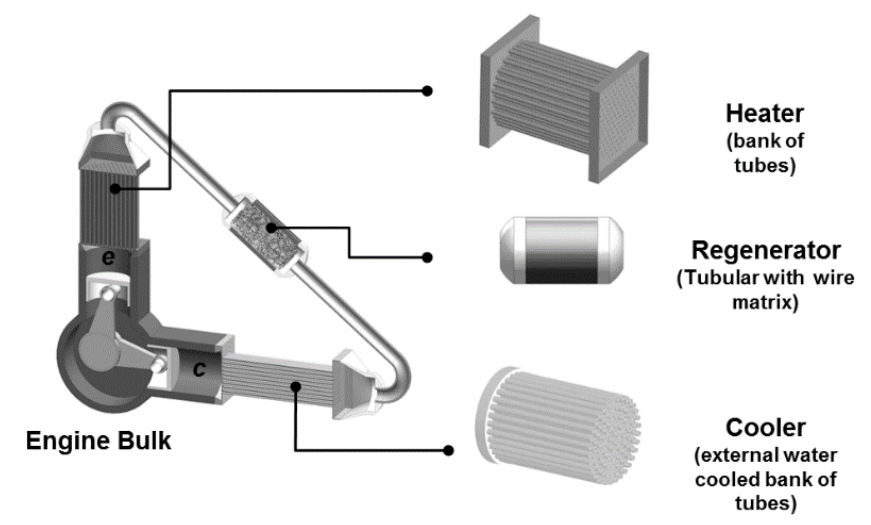

Figure 2 Stirling engine components (A. C. Ferreira, Oliveira, Nunes, Martins, \& Teixeira, 2014)

Stirling engine has two pistons in different arrangement and a heat exchanger called the regenerator. The spaces between the regenerator and the pistons are called the compression and the expansion spaces. The piston rods are connected to the crankshaft by connecting rods. The expansion space must be maintained at a high temperature while the compression volume must be maintained at a low temperature.

The heater is a heat exchanger that is responsible for the heat transfer from the heat source to the operating fluid throughout a mesh of tubes that absorbs the heat from the receiver to the working gas. The most used configuration for the heater is smooth pipes in a parallel arrangement.

The regenerator is the heat exchanger that distinguishes the Stirling engine from other types of engines. The regenerator usually contains a fine mesh matrix of metal wires. The aim of the matrix is to absorb and release heat from and back to the working gas.

The cooler aims to absorb heat from the working gas adjacent to the compression space and reject the heat absorbed. The most common method of cooling in Stirling engines is water cooling, while air cooling is less common (A. C. M. Ferreira et al., 2014).

The Stirling engine thermodynamic cycle for a two-cylinder Alpha-type Stirling engine is characterized by four different phases: expansion, pre-cooling transfer, compression, and pre-heating transfer as shown in Figure 3 (Urieli \& Berchowitz, 1984). 


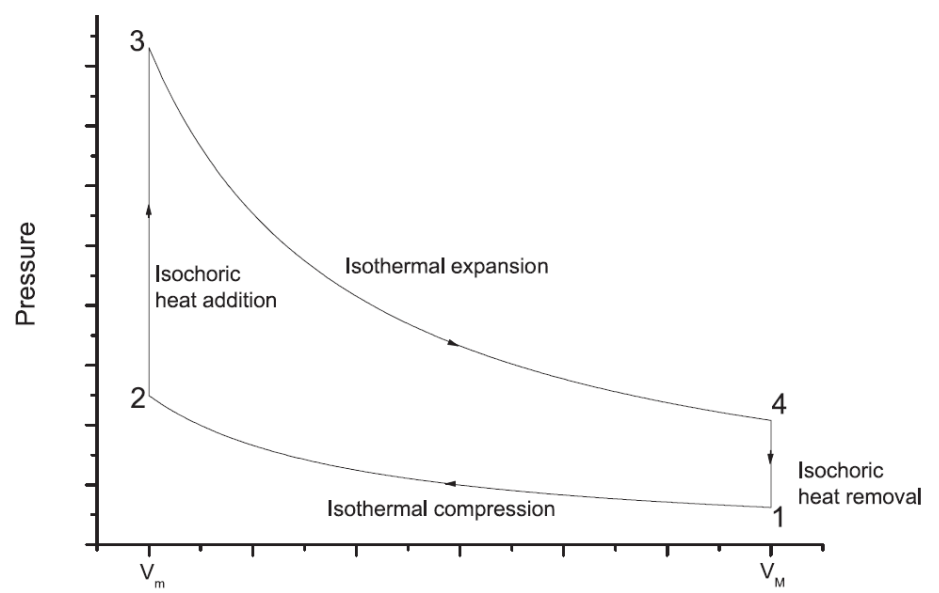

Figure 3 Ideal Stirling cycle (A. C. Ferreira et al., 2014)

\section{System models}

\subsection{Solar dish concentrator model}

There are several parameters affecting the design and modelling of the solar concentrator including the type of the reflective material of the concentrator, diameter of the paraboloid dish concentrator, sizing of the aperture area of the concentrator that affect the sizing of the aperture area of the solar receiver, focal length of the dish, focal point diameter, rim angle, and finally the concentration ratio, which is the most important parameter as it shows the amount of solar energy concentrated to the receiver (Shazly et al., 2014) and (Hafez et al., 2016).

The amount of concentrated energy intercepted by the receiver from the concentrator can be calculated using the term that defines this amount from the fundamental solar collection equation (William B. Stine and Richard B. Diver, 1994).

$$
Q_{\text {rec }, \text { int }}=D N I A_{\text {rec }} E \cos \theta_{i} \rho_{\text {con }} \varphi_{\text {rec }} \tau \alpha_{\text {rec }}
$$

Where $\tau$ is the transmittance of anything between the concentrator and the receiver, such as window covering of the receiver.

\subsection{Receiver Model}

Conduction, convection, and radiation are having a large fraction of the total energy losses of the DS system through the receiver. Conduction losses are a small proportion of the total losses and can be controlled by modifying the insulation thickness of the receiver. Natural convection losses contribute about forty $40 \%$ of the total receiver losses and is dependent on wind velocity Long-wave length radiation losses form about $60 \%$ of the total losses in a DS system and are minimized by increasing the absorptance of the cavity, maximizing the surface area of the cavity, adding a transparent glass window aperture cover, or by minimizing the aperture diameter. Figure 4 shows the cavity receiver geometry and energy balance of the receiver. 

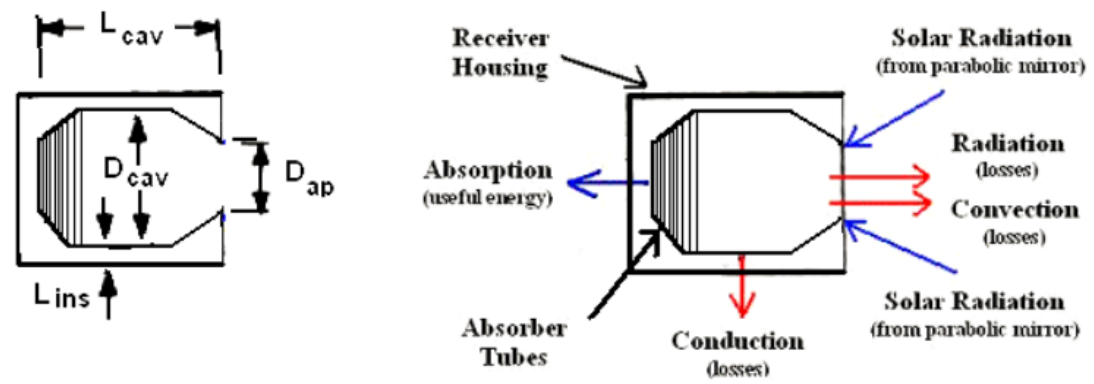

Figure 4 Cavity receiver geometry (left) and energy balance (right) diagrams (Fraser \& Klein, 2008)

\subsubsection{Conduction Losses}

Receiver conduction losses represent a small percentage of the overall receiver thermal losses. Conduction through the receiver housing occurs at a high rate when the temperature of the receiver and absorber walls increases. Conduction losses are dependent on the convective heat transfer on the exterior of the receiver housing. A series resistance model can be used to obtain the total conductive losses.

$$
\dot{Q}_{\text {cond }}=\frac{T_{w}-T_{a m b}}{R_{\text {cond }}+R_{\text {conv }}}
$$

Where $\mathrm{R}_{\text {cond }}$ and $\mathrm{R}_{\text {conv }}$ for planar geometries can be described as:

\subsubsection{Convection losses}

$$
\begin{aligned}
\boldsymbol{R}_{\text {th,cond }} & =\frac{L}{k A_{\text {cond }}} \\
\boldsymbol{R}_{\text {th,conv }} & =\frac{1}{h A_{\text {conv }}}
\end{aligned}
$$

Convection losses represent a significant percentage of the total DS system losses. Convection losses are a function of cavity geometry, cavity temperature, aperture orientation and diameter, and wind velocity. It is also dependent on the time of the year and location (William B. Stine and Richard B. Diver, 1994).

$$
\begin{aligned}
& Q_{\text {total,conv }}=Q_{\text {natural }}+Q_{\text {forced }} \\
& h_{\text {total,conv }}=h_{\text {natural }}+h_{\text {forced }}
\end{aligned}
$$

\subsubsection{Radiation Losses}

Radiation losses in the receiver represent a significant percentage of the total losses in the receiver losses. According to experimental results from Sandia National Labs (Hogan, Diver, \& Stine, 1990), it represents nearly 60\% of the receiver losses during morning and evening and about $75 \%$ at noon. Unlike the convective losses, radiation losses are relatively constant throughout the day (Hogan et al., 1990).

Radiation losses contribute to losses from the receiver through two ways. The first is radiation due to emission from the aperture due to the large temperature difference between the cavity walls and the paraboloid mirror (Hogan et al., 1990). 


$$
\dot{Q}_{\text {radiation }}=\varepsilon_{\text {cav }} \sigma A_{a p}\left(T_{c a v}^{4}-T_{a m b}^{4}\right)
$$

The radiation losses due to the reflection off the cavity surface are determined by the effective absorptance of the cavity receiver. Which is estimated to be 0.87 (Hogan et al., 1990).

$$
\begin{gathered}
\alpha_{e f f}=\frac{\alpha_{c a v}}{\alpha_{c a v}+\left(1-\alpha_{c a v}\right)\left(A_{a p} / A_{\text {cav }, \text { tot }}\right)} \\
\dot{Q}_{\text {rad,reflect }}=\left(1-\alpha_{e f f}\right) \dot{Q}_{\text {in,receiver }}
\end{gathered}
$$

\subsubsection{Cavity Geometry Influence on Radiation}

The cavity geometry influences the radiation losses. The receiver cavity has several geometries used. The geometry of the receiver has less than three percent effect on the receiver performance (Harris \& Lenz, 1985) and just modifies the flux distribution on the absorber (Hogan et al., 1990).

\subsection{Stirling engine model}

The Stirling engine analysis consists of elaboration and validation of an ideal isothermal model, an ideal adiabatic model, and non-ideal analysis to evaluate the heat transfer and the flow-friction effects of the heater, regenerator, and cooler.

\subsubsection{Ideal Isothermal (Schmidt) analysis}

There are a set of assumptions for the ideal isothermal analysis. The compression and expansion spaces are considered to have constant temperatures. The regenerator temperature is a linear function between $T_{k}$ and $T_{h}$. The compression space temperature $T_{c}$ is constant and equal to $T_{k}$. The expansion space temperature $T_{e}$ is constant and equal to $T_{h}$ as shown in Figure 5. The total mass of the working gas is constant.

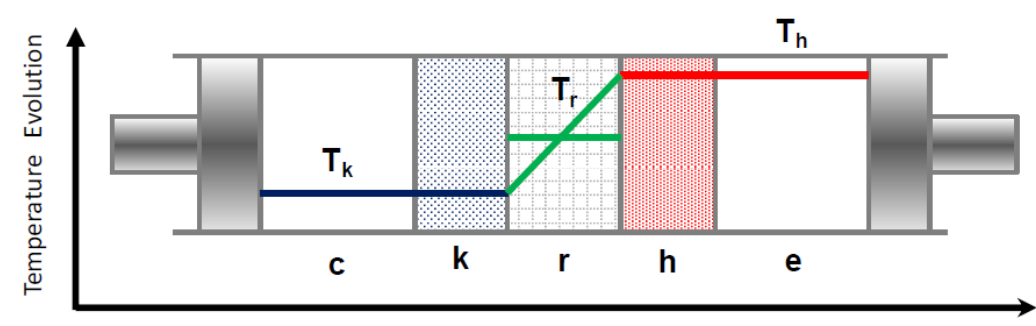

Figure 5 Ideal isothermal analysis temperature flow diagram (Alpha-type engine) (A. C. M. Ferreira et al., 2014)

Considering the previous assumptions, the Schmidt ideal isothermal analysis aims to calculate the total mass of the working gas using the ideal gas law, the regenerator temperature, sinusoidal compression, and expansion space volumes are calculated to obtain the working gas pressure equation.

where,

$$
p=M R /\left[s+\left(\frac{V_{s w e} \cos \alpha}{2 T_{h}}+\frac{V_{s w c}}{2 T_{k}}\right) \cos \theta-\left(\frac{V_{s w e} \sin \alpha}{2 T_{h}}\right) \sin \theta\right]
$$




$$
s=\left[\frac{V_{s w c}}{2 T_{k}}+\frac{V_{c l c}}{T_{k}}+\frac{V_{k}}{T_{k}}+\frac{V_{r} \ln \left(T_{h} / T_{k}\right)}{\left(T_{h}-T_{k}\right)}+\frac{V_{h}}{T_{h}}+\frac{V_{s w e}}{2 T_{h}}+\frac{V_{c l e}}{T_{e}}\right]
$$

The net work done by the Stirling engine is the sum of the work done by the expansion and compression spaces over the cycle.

$$
\begin{aligned}
Q_{e}=W_{e} & =\int_{0}^{2 \pi}\left(p \frac{d V_{e}}{d \theta}\right) d \theta \\
Q_{c}=W_{c} & =\int_{0}^{2 \pi}\left(p \frac{d V_{c}}{d \theta}\right) d \theta \\
W & =W_{c}+W_{e}
\end{aligned}
$$

For the ideal isothermal analysis, the heat transfer $\mathrm{Q}$ is equal to the work done W. For the three heat exchangers, $Q$ is equal to zero. Like the Carnot efficiency, the total Stirling engine efficiency is said to be equal to the total work divided by the heat transferred to the expansion space.

$$
\eta=\frac{W}{Q_{e}}
$$

In the isothermal analysis neither the heater nor the cooler contributes to any heat transfer over the cycle. The main disadvantage of this analysis is that it doesn't predict the real cycle.

\subsubsection{Ideal adiabatic analysis}

In the ideal adiabatic analysis, the compression and expansion spaces are adiabatic. This leads to a set of assumptions. There is no leakage happens from the working gas. The temperatures $T_{c}$ and $T_{e}$ are not constant and vary over the compression and expansion phases of the Stirling cycle as shown in Figure 6. The total mass of the working gas $\mathrm{M}$ is constant. Work is done by the volume variations of the compression space $\mathrm{V}_{\mathrm{c}}$ and the expansion space $\mathrm{V}_{\mathrm{e}}$ respectively. $\mathrm{Q}_{\mathrm{k}}$ and $\mathrm{Q}_{\mathrm{h}}$ are only transferred between the external environment and the working gas in the cooler and heater respectively. $\mathrm{Q}_{\mathrm{r}}$ is transferred internally between the regenerator matrix and the working gas. Each engine compartment is considered as a separate cell as shown in Figure 7, Enthalpy is transported into and out of the cell by means of mass flow and temperature.

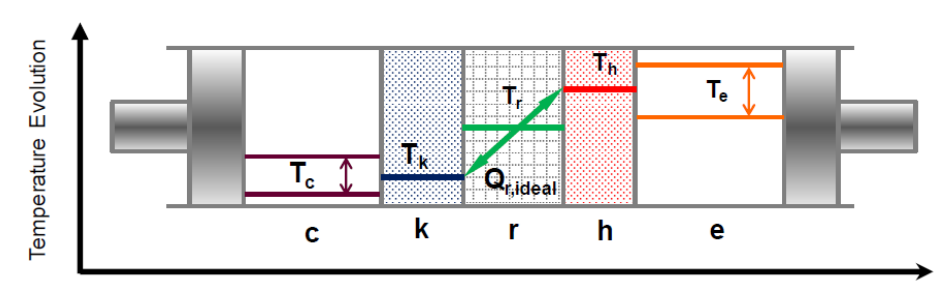

Figure 6 Ideal adiabatic analysis temperature flow diagram (Alpha-type engine) (A. C. M. Ferreira et al., 2014) 


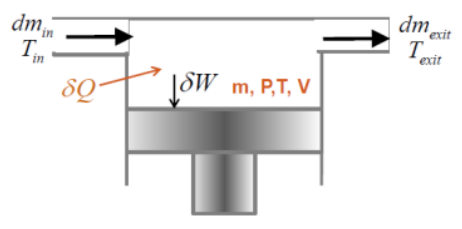

Figure 7 Stirling engine generalized cell (A. C. M. Ferreira et al., 2014)

Energy transferred for each heat exchangers can be calculated by applying the energy equation to each heat exchanger and substituting for the equation of state.

$$
\begin{aligned}
\boldsymbol{d} Q_{k} & =\frac{V_{k} \boldsymbol{d} p c_{v}}{R}-c_{p}\left(T_{c k} \dot{m}_{c k}-T_{k r} \dot{m}_{k r}\right) \\
\boldsymbol{d} Q_{r} & =\frac{V_{r} \boldsymbol{d} p c_{v}}{R}-c_{p}\left(T_{k r} \dot{m}_{k r}-T_{r h} \dot{m}_{r h}\right) \\
\boldsymbol{d} Q_{h} & =\frac{V_{h} \boldsymbol{d} p c_{v}}{R}-c_{p}\left(T_{r h} \dot{m}_{r h}-T_{h e} \dot{m}_{h e}\right)
\end{aligned}
$$

The work done in the compression and expansion spaces can be given by.

$$
\begin{gathered}
W=W_{c}+W_{e} \\
\boldsymbol{d} W=\boldsymbol{d} W_{c}+\boldsymbol{d} W_{e} \\
\boldsymbol{d} W_{c}=p \boldsymbol{d} V_{c} \\
\boldsymbol{d} W_{e}=p \boldsymbol{d} V_{e}
\end{gathered}
$$

The independent differential equations are solved simultaneously for the seven unknown variables $\left(\mathrm{T}_{\mathrm{c}}, \mathrm{T}_{\mathrm{e}}, \mathrm{Q}_{\mathrm{k}}, \mathrm{Q}_{\mathrm{r}}, \mathrm{Q}_{\mathrm{h}}, \mathrm{W}_{\mathrm{c}}, \mathrm{W}_{\mathrm{e}}\right)$. The objective of the simulation is to find an unknown function that satisfies both the differential equations and the initial conditions. Classical fourth-order Runge-Kutta method is used to numerically solve the equations until convergence conditions are reached. The equation set consists of 22 variables and 7 derivatives to be solved over a complete Stirling cycle.

\subsubsection{Non-Ideal analysis}

The heat exchanged inside the heater and the cooler is non-ideal. As a result, the gas temperature inside the heater decreases while the gas temperature inside the cooler increases for a given set of wall temperatures. The temperature difference between the walls and the working gas is evaluated by means of heat exchange coefficient, assuming forced convection inside the heat exchangers. This leads to a more realistic analysis that permits a sensitivity analysis as required for an optimal heat exchangers design. Figure 8 shows the temperature distribution between the Alpha-type Stirling engine compartments. 


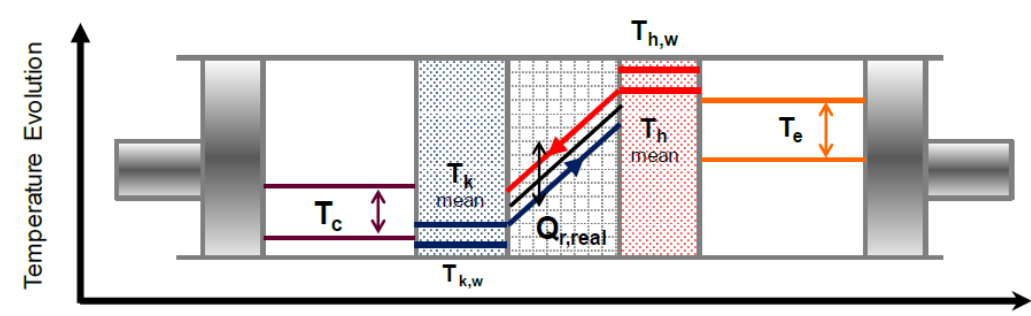

Figure 8 non-ideal analysis temperature flow diagram (Alpha-type engine) (A. C. M. Ferreira et al., 2014)

In the non-ideal analysis, the heat capacity of the regenerator is very small. This leads to an increase in the temperature difference between the hot source and cold sink temperature. This non-ideal effect of the regenerator happens due to the convective thermal resistance between the regenerator surface and the working gas (Urieli \& Berchowitz, 1984). This can be computed using the Number of Transfer Units (NTU) defined as a function of the heat exchanger size. the NTU method is used to calculate the heat transfer in the heat exchangers.

$$
N T U=\frac{h A_{w g}}{\rho u c_{p} A}
$$

NTU is used to compute the regenerator effectiveness $\varepsilon_{r}$ which can be defined as the ratio between the real amount of exchanged heat between the working fluid and the regenerator matrix, and the maximum amount of heat transferred in the regenerator adiabatically.

$$
\varepsilon_{r}=\frac{N T U}{(1+N T U)}
$$

The regenerator heat transfer reduction $\left(\mathrm{Q}_{\mathrm{rloss}}\right)$ can be obtained as a function of regenerator effectiveness and the amount of heat transferred by the regenerator in the adiabatic analysis $\dot{Q}_{r, \text { ideal }}$.

$$
\dot{Q}_{r l o s s}=\left(1-\varepsilon_{r}\right) \dot{Q}_{r, \text { ideal }}
$$

The effectiveness of the heater and cooler are the same and can be defined as by means of NTU.

$$
\varepsilon=1-e^{-N T U}
$$

The actual heat for the cooler and heater can be described as.

$$
\begin{aligned}
& \dot{Q}_{h}=\dot{Q}_{h, \text { ideal }}+\dot{Q}_{\text {rloss }} \\
& \dot{Q}_{k}=\dot{Q}_{k, \text { deal }}+\dot{Q}_{\text {rloss }}
\end{aligned}
$$

The flow-friction effect of the working gas flowing through the heat exchangers affects the engine performance because it results in a pressure drop or pumping loss. The pumping loss corresponds to the work required to let the working gas move through the heat exchangers and results in the reduction of the power output of the engine. The pressure drop is calculated for the three heat exchangers, then the value of the corresponding work can be formulated by integrating over the complete cycle. 


$$
W=\int_{0}^{2 \pi} p\left(d V_{e}+d V_{c}\right)-\int_{o}^{2 \pi}\left(\sum_{i=1}^{3} \Delta p_{i} \frac{d V_{e}}{d \theta}\right) d \theta
$$

Where the first term of the previous equation represents the ideal adiabatic work done per cycle, while the second term represents the work losses.

\section{Simulation Strategy}

In the previous section, the model of every component of the system is discussed. A comprehensive model using MATLAB software was created using different models of components as shown in Figure 9. The system input is the Direct Normal Irradiance (DNI) coming from the sun at certain locations, while the system outputs are the efficiency, output power and heat transferred in different Stirling engine compartments.

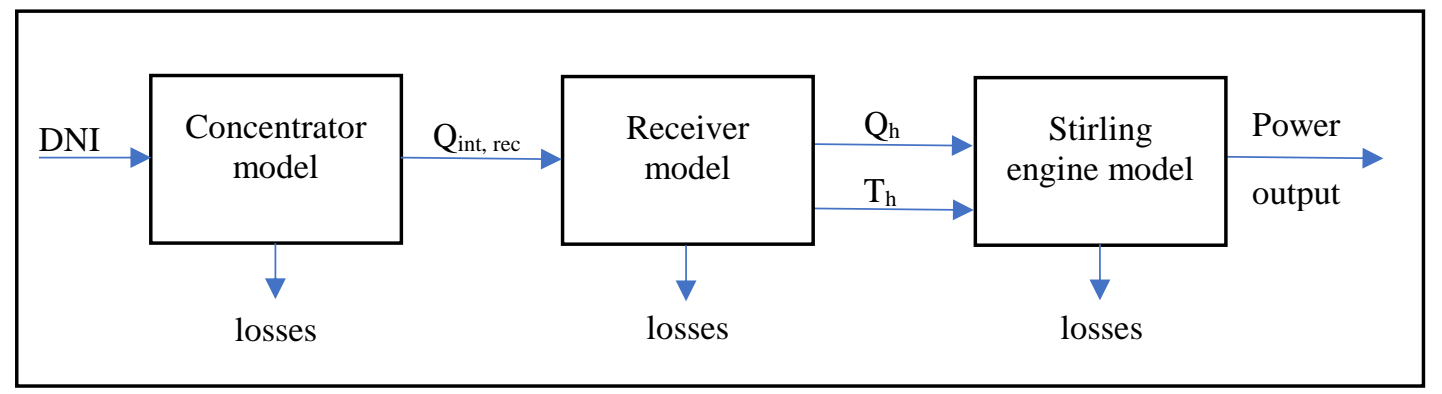

Figure 9 Simulation strategy flow chart

\subsection{System model parameters}

Table 1 presents the concentrator and receiver parameters, engine dimensions, working gas type, and operating parameters. The concentrator and receiver sizing are based on the size of the Stirling engine which is a theoretical model presented by (A. C. Ferreira et al., 2014) which has the same geometry of the SOLO V161 Stirling engine, but has smaller piston swept volume. The SOLO V161 Stirling has swept volume of $160 \mathrm{~cm}^{3}$, while the modelled engine has swept volume of $130 \mathrm{~cm}^{3}$. It was assumed that both engines have the same materials. This leads to scaling both the concentrator and the receiver dimensions. The modelled concentrator dish has $6.6 \mathrm{~m}$ aperture diameter which was calculated in order to choose a dish size suitable for the size of the Stirling engine. The concentrator dish of the Eurodish unit that uses SOLO V161 has a concentrator aperture diameter of $8.8 \mathrm{~m}$ (Keck, Schiel, Reinalter, \& Heller, 2002). This leads to choosing smaller aperture diameter in order to prevent overheating of the engine.

The MATLAB model uses the data to define the engine parameters for every engine component and operating conditions. After the definition of parameters and conditions, a Schmidt ideal-isothermal analysis to calculate the mass of the working gas and other isothermal based analysis data. An ideal-adiabatic analysis is then performed on the modeled engine. Finally, a non-ideal analysis to calculate the pumping losses and obtain accurate results is performed. The three types of analysis are based on (Urieli \& Berchowitz, 1984). 
Table 1 Simulation parameters and system component dimensions

\begin{tabular}{|c|c|c|c|c|c|c|}
\hline \multicolumn{7}{|c|}{ Concentrator parameters } \\
\hline \multirow{2}{*}{ Reflective material } & \multirow{2}{*}{ Aluminum } & \multirow{2}{*}{ Reflectivity } & \multirow{2}{*}{$92.5 \%$} & \multicolumn{2}{|c|}{$\begin{array}{l}\text { Aperture } \\
\text { diameter }\end{array}$} & $6.6 \mathrm{~m}$ \\
\hline & & & & \multicolumn{2}{|c|}{$\begin{array}{l}\text { Aperture } \\
\text { area }\end{array}$} & $34.2 \mathrm{~m}^{2}$ \\
\hline \multicolumn{7}{|c|}{ Receiver parameters } \\
\hline \multirow{3}{*}{ Receiver material } & \multirow{3}{*}{ Inconel } & \multirow[t]{2}{*}{ Absorptance } & \multirow[t]{2}{*}{$93 \%$} & \multicolumn{2}{|c|}{$\begin{array}{l}\text { Aperture } \\
\text { diameter }\end{array}$} & $0.178 \mathrm{~m}$ \\
\hline & & & & \multirow{2}{*}{\multicolumn{2}{|c|}{$\begin{array}{l}\text { Aperture } \\
\text { area }\end{array}$}} & $0025 \mathrm{~m}^{2}$ \\
\hline & & Emittance & $88.9 \%$ & & & 0.025111 \\
\hline Insulation & \multicolumn{6}{|c|}{ Ceramic } \\
\hline \multicolumn{7}{|c|}{ Stirling engine dimensions and operating parameters } \\
\hline Engine Type & \multicolumn{6}{|c|}{ Alpha-type } \\
\hline \multicolumn{7}{|c|}{ Expansion and compression spaces (similar) } \\
\hline Clearance volume & \multicolumn{6}{|c|}{$2.5 \mathrm{e}-5 \mathrm{~m}^{3}$} \\
\hline Swept volume & \multicolumn{6}{|c|}{$0.00013 \mathrm{~m}^{3}$} \\
\hline Cylinder bore & \multicolumn{6}{|c|}{$63.5 \mathrm{~mm}$} \\
\hline Cylinder Stroke & \multicolumn{6}{|c|}{$41 \mathrm{~mm}$} \\
\hline \multicolumn{7}{|c|}{ Heat exchangers } \\
\hline Heat exchanger & \multicolumn{2}{|c|}{ Cooler } & \multicolumn{4}{|c|}{ Heater } \\
\hline Heat exchanger type & \multicolumn{2}{|c|}{ Smooth pipes } & \multicolumn{4}{|c|}{ Smooth pipes } \\
\hline Internal diameter & \multicolumn{2}{|c|}{$0.003 \mathrm{~m}$} & \multicolumn{4}{|c|}{$0.003 \mathrm{~m}$} \\
\hline Number of tubes & & 50 & & 8 & & \\
\hline Heat exchanger length & & $1 \mathrm{~m}$ & & 0.1 & & \\
\hline & Regene & rator heat exch & hanger & & & \\
\hline $\begin{array}{c}\text { Regenerator } \\
\text { Configuration }\end{array}$ & Tubular re & enerator & $\begin{array}{r}\text { Regenerato } \\
\text { type }\end{array}$ & matrix & & sh matrix \\
\hline External diameter & 0.05 & & Number o & ubes & & 1 \\
\hline Internal diameter & 0.04 & & Matrix pc & sity & & 0.7 \\
\hline Regenerator length & 0.06 & & $\begin{array}{r}\text { Wire } \mathrm{m} \\
\text { diame }\end{array}$ & & & $0003 \mathrm{~m}$ \\
\hline & & Working gas & & & & \\
\hline Working gas type & & & Hydrogen & & & \\
\hline & Oper & tional parame & eters & & & \\
\hline Hot source temperature & & $\operatorname{Rec}$ & ceiver outp & & & \\
\hline Cold sink temperature & & & $353 \mathrm{~K}\left(80^{\circ}\right.$ & & & \\
\hline Phase angle & & & 90 degree & & & \\
\hline Mean pressure & & & $8 \mathrm{e}+6 \mathrm{~Pa}$ & & & \\
\hline $\begin{array}{l}\text { Engine speed } \\
\text { (frequency) }\end{array}$ & & & $00 \mathrm{rpm} / 50$ & & & \\
\hline
\end{tabular}

\subsection{Model validation and verification}

Validation was performed by comparing the model output with published experimental results. The concentrator and receiver model was validated by comparing the results with the experimental results of (Reinalter et al., 2008) as 
shown in Table 2 By applying the same parameters of concentrator and receiver dimensions and operating conditions, and an input DNI of $907 \mathrm{~W} / \mathrm{m}^{2}$, the thermal power transferred into the Stirling engine was resulted as $20.73 \mathrm{~kW}$, while the experimental output was $30.77 \mathrm{~kW}$ with an error percentage of $32.6 \%$. The large error percentage is due to the assumptions made in the receiver losses model and can be solved by performing an accurate heat transfer analysis with experimental measurements, which was not possible during the research.

Table 2 Concentrator and receiver model validation

\begin{tabular}{|c|c|c|c|c|}
\hline \multicolumn{5}{|c|}{ Concentrator and receiver models } \\
\hline Output Parameter & Output value & Reference output & Unit & $\%$ error \\
\hline $\begin{array}{c}\text { Thermal power transferred to the } \\
\text { Stirling engine by the receiver }\end{array}$ & 20.73 & 30.77 & $\mathrm{~kW}$ & $\approx 32.6 \%$ \\
\hline
\end{tabular}

The Stirling engine model was verified by comparing the model results by the results obtained by (A. C. M. Ferreira et al., 2014). The engine parameters were originally obtained from this reference. (A. C. M. Ferreira et al., 2014) performed a detailed economic and thermodynamic modeling of the Stirling engine, and used several operating parameters to obtain the best parameter values such as mean pressure and operating frequency. The comparison was performed on the engine working with 25 $\mathrm{Hz}$ frequency, 3 bar mean working gas pressure, and $725 \mathrm{~K}$ heater temperature. The results were very close to the reference results as shown in Table 3.

Table 3 Stirling engine model validation

\begin{tabular}{|c|c|c|c|c|}
\hline Output Parameter & Output value & Reference output & Unit & $\%$ error \\
\hline \multicolumn{5}{|c|}{ Schmidt analysis } \\
\hline Power & 1573 & 1572 & $\mathrm{~W}$ & $\approx 0 \%$ \\
\hline indicated efficiency & 51.3 & 51.3 & $\%$ & $\approx 0 \%$ \\
\hline \multicolumn{5}{|c|}{ Ideal Adiabatic analysis } \\
\hline Total power output & 1517.88 & 1471 & $\mathrm{~W}$ & $\approx 3.2 \%$ \\
\hline Thermal efficiency & 45.8 & 43.0 & $\%$ & $\approx 6.5 \%$ \\
\hline \multicolumn{5}{|c|}{ Non-ideal analysis } \\
\hline Actual power & 1284.9 & 1390.4 & $\mathrm{~W}$ & $\approx-10.1 \%$ \\
\hline Actual efficiency & 28.3 & 31.6 & $\%$ & $\approx-10.44 \%$ \\
\hline
\end{tabular}

\section{Simulation results}

The simulation was conducted using different input DNI for different zones assigned by the Egyptian government for renewable energy projects. The locations of these zones and the yearly average DNI for CSP applications are published in the Solar Atlas of Egypt by the National Renewable Energy Agency (El-Askary, Kosmopoulos, $\&$ Kazadzis, 2018). The DNI data of these zones in addition to three more zones to cover the Egyptian map was obtained using METEONORM software.

\subsection{DS system performance in different zones in Egypt}

The data of the zones that were studied using the system model, their location, their yearly average DNI, the output power in Watts and the engine efficiency are presented 
in Table 4. Figure 10 presents a graphical comparison between the different zones by means of the output pressure. Figure 11 presents a comparison between the locations by means of engine efficiency.

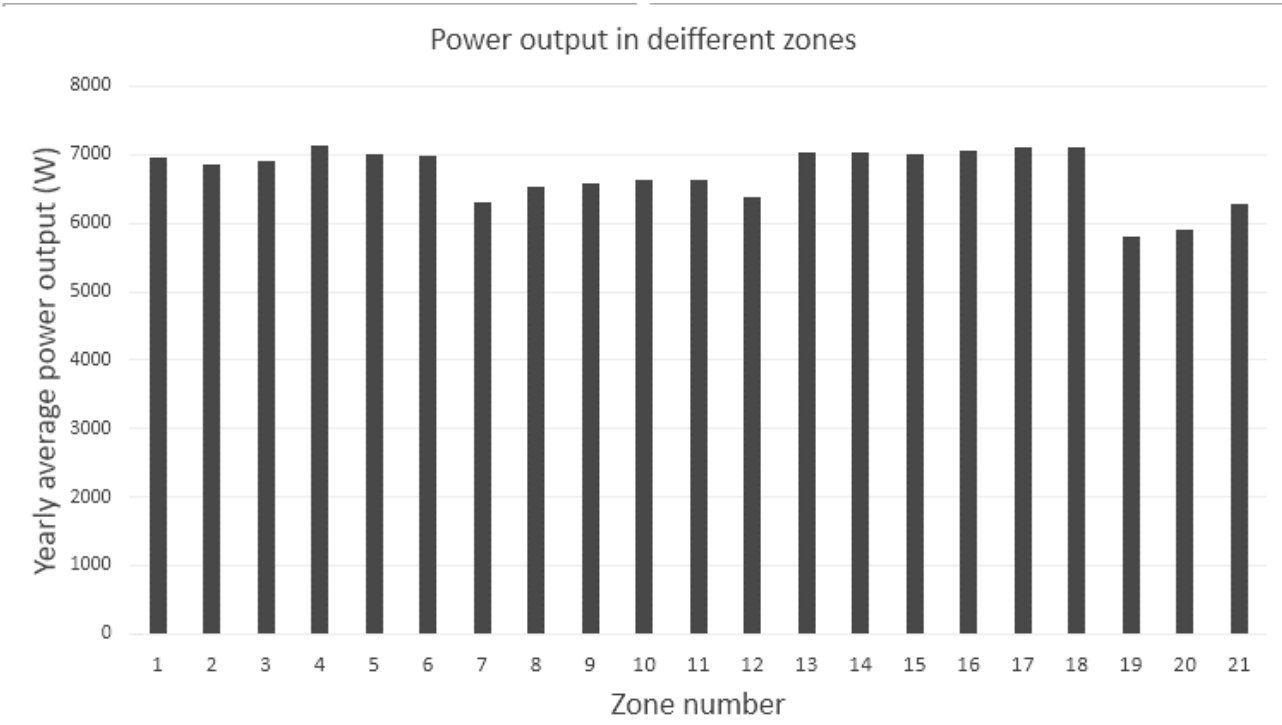

Figure 10 Yearly average output power for the studied zones

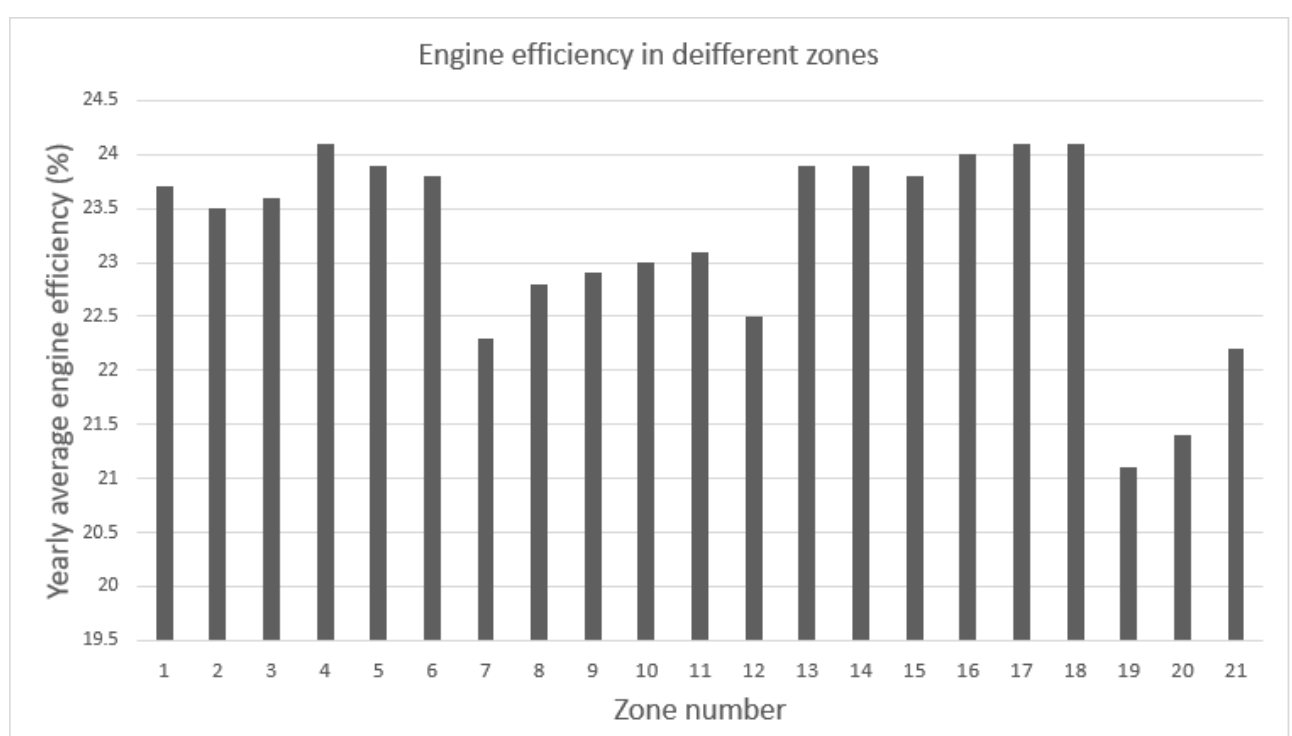

Figure 11 Yearly average engine efficiency for the studied zones 
Table 4 Studied zones with inputs (DNI) and outputs (output power and efficiency)

\begin{tabular}{|c|c|c|c|c|c|}
\hline$\#$ & Location Name & Coordinates & $\begin{array}{l}\text { DNI (Yearly } \\
\text { average) } \\
\left(\mathrm{W} / \mathrm{m}^{2}\right) \\
\end{array}$ & $\begin{array}{l}\text { Output } \\
\text { Power } \\
\text { (W) }\end{array}$ & $\begin{array}{l}\text { Engine } \\
\text { Efficiency } \\
(\%) \\
\end{array}$ \\
\hline \multicolumn{6}{|c|}{ Red sea coast zone } \\
\hline 1 & Hurghada (Al Ahyaa) & $27.16^{\circ} \mathrm{E}, 33.46^{\circ} \mathrm{N}$ & 313.58 & 6950.7 & 23.7 \\
\hline 2 & Hurghada (Kilo 10) & $27.18^{\circ} \mathrm{E}, 33.42^{\circ} \mathrm{N}$ & 304.79 & 6858.9 & 23.5 \\
\hline 3 & Marsa Alam location & $26.50^{\circ} \mathrm{E}, 33.54^{\circ} \mathrm{N}$ & 309.6 & 6909.3 & 23.6 \\
\hline 4 & Gebel El-Ziet location & $28.12^{\circ} \mathrm{E}, 33.20^{\circ} \mathrm{N}$ & 332.07 & 7135.5 & 24.1 \\
\hline 5 & Sharm El-Sheikh & $27.71^{\circ} \mathrm{E}, 34.18^{\circ} \mathrm{N}$ & 319.9 & 7015 & 23.9 \\
\hline \multicolumn{6}{|c|}{ Suez Governorate } \\
\hline 6 & El Zaafarana & $27.16^{\circ} \mathrm{E}, 33.46^{\circ} \mathrm{N}$ & 315.9 & 6974.4 & 23.8 \\
\hline \multicolumn{6}{|c|}{ Northern Coast } \\
\hline 7 & Ras El Hekma & $31.122^{\circ} \mathrm{N}, 27.52^{\circ} \mathrm{E}$ & 256.8 & 6308.4 & 22.3 \\
\hline 8 & Baghoush & $31.925^{\circ} \mathrm{N}, 27.395^{\circ} \mathrm{E}$ & 275.4 & 6532.2 & 22.8 \\
\hline 9 & El- Mathany & $31.232^{\circ} \mathrm{N}, 26.474^{\circ} \mathrm{E}$ & 278.9 & 6573.2 & 22.9 \\
\hline 10 & El Galalah & $31.145^{\circ} \mathrm{N}, 28.11^{\circ} \mathrm{E}$ & 282.9 & 6619.1 & 23 \\
\hline 11 & Al Rowaysat & $30.48^{\circ} \mathrm{N}, 29.19^{\circ} \mathrm{E}$ & 284.4 & 6636 & 23.1 \\
\hline \multicolumn{6}{|c|}{ Al Kuraymat } \\
\hline 12 & Al Kuraymat & $29.163^{\circ} \mathrm{N}, 31.148^{\circ} \mathrm{E}$ & 262.1 & 6373.8 & 22.5 \\
\hline \multicolumn{6}{|c|}{ West and East Nile } \\
\hline 13 & Land number three & $28.3^{\circ} \mathrm{N}, 30.15^{\circ} \mathrm{E}$ & 322.4 & 7040.1 & 23.9 \\
\hline 14 & Land number two & $27.8^{\circ} \mathrm{N}, 31.1^{\circ} \mathrm{E}$ & 321.8 & 7034.1 & 23.9 \\
\hline 15 & Location 1 & $28.3^{\circ} \mathrm{N}, 31.15^{\circ} \mathrm{E}$ & 318.6 & 7001.9 & 23.8 \\
\hline \multicolumn{6}{|c|}{ East Nile Zone } \\
\hline 16 & East Nile Zone & $28^{\circ} \mathrm{N}, 31^{\circ} \mathrm{E}$ & 325 & 7066 & 24 \\
\hline \multicolumn{6}{|c|}{ Aswan } \\
\hline 17 & Benban & $24.25^{\circ} \mathrm{N}, 32.43^{\circ} \mathrm{E}$ & 329.34 & 7108.8 & 24.1 \\
\hline 18 & Fares & $24.37^{\circ} \mathrm{N}, 32.5^{\circ} \mathrm{E}$ & 330.47 & 7119.9 & 24.1 \\
\hline \multicolumn{6}{|c|}{ Other locations } \\
\hline 19 & El Natroon & $30.4^{\circ} \mathrm{N}, 30.35^{\circ} \mathrm{E}$ & 219 & 5799.5 & 21.1 \\
\hline 20 & El Arish & $31.08^{\circ} \mathrm{N}, 33.83^{\circ} \mathrm{E}$ & 227 & 5913.8 & 21.4 \\
\hline 21 & Kharga & $25.45^{\circ} \mathrm{N}, 30.53^{\circ} \mathrm{E}$ & 254.2 & 6275.7 & 22.2 \\
\hline
\end{tabular}

The highest results obtained from zone number 18 in Fares, Aswan with coordinates of $24.37 \mathrm{~N}, 32.5 \mathrm{E}$. The outputs of Fares zone were $7119.9 \mathrm{~W}$ of output power and $24.1 \%$ efficiency (yearly average), while the work loss due to pressure drop was calculated as $189.1 \mathrm{~W}$. El-Natroon zone $\left(30.4^{\circ} \mathrm{N}, 30.35^{\circ} \mathrm{E}\right)$ showed the least power output value of $5799.5 \mathrm{~W}$ with $21.1 \%$ engine efficiency and $197 \mathrm{~W}$ work loss due to pressure drop. The overall results show good indications for using the DS systems under Egyptian operating conditions. Figure 12 and Figure 13 shows the Pv and energy vs crank angle diagrams for Fares and El-Natroon zones respectively. 


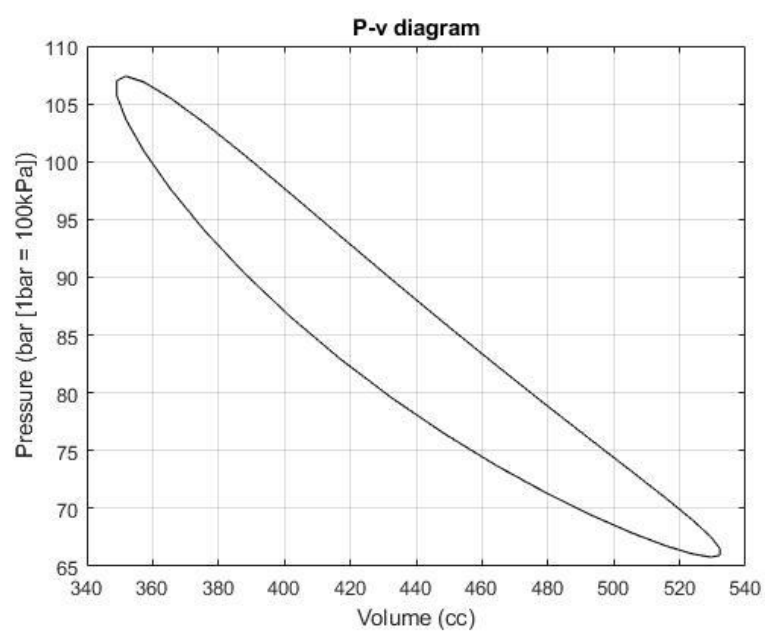

Figure 12 Pressure-Volume diagram for Fares zone

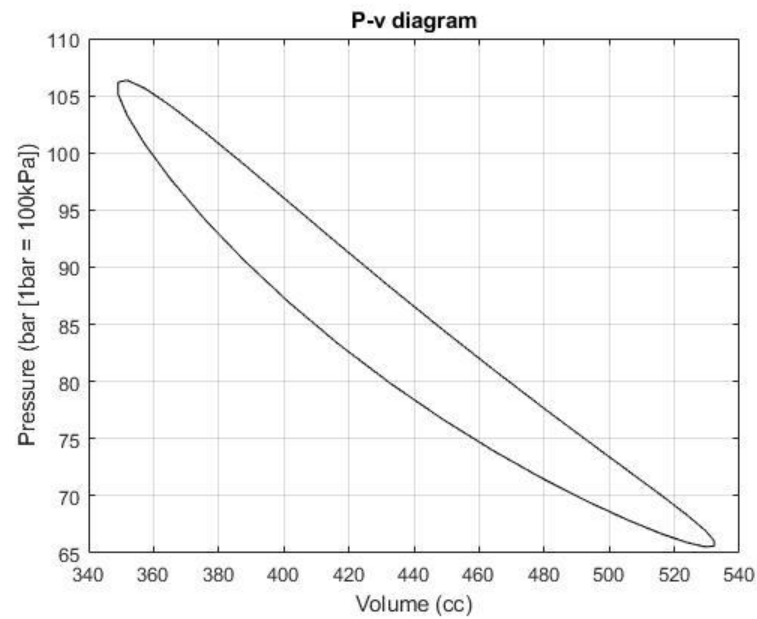

Figure 13 Pressure-Volume diagram for El-Natroon zone

\subsection{Comparison between DS and PV system performance}

The DS system is considered to have one of the highest efficiencies compared to other solar energy technologies. A comparison is done between the simulated DS system and a simulated PV system by means of the total land occupied by the systems, and the overall system efficiencies. The simulation of the PV systems was done using System Advisor Model (SAM) software, which is a reliable renewable energy simulation tool developed and distributed by the U.S. Department of Energy's National Renewable Energy Laboratory. The selected location to conduct the comparison is Aswan. The latitude and longitude are $23.97^{\circ} \mathrm{N}$ and $32.78^{\circ} \mathrm{E}$ respectively. The SAM database gave a DNI of $6.67 \mathrm{kWh} / \mathrm{m}^{2} /$ day, which means that the simulation will run at $277.91 \mathrm{~W} / \mathrm{m}^{2}$. Using the given DNI, the DS simulation model gave $5.6 \mathrm{~kW}$ output power. The simulation of the PV system using Sam to produce the same power output. the solar module model used is JKMS300M-72 produced by Jinko Solar, which is a polycrystalline solar module that produce $300 \mathrm{~W}$ with nominal efficiency of $15.47 \%$. 
The PV simulation using SAM software results gave a total of 2 strings in parallel with 9 modules per each string with tilt angle of 30 degrees and ground coverage ratio (GCR) of 0.5 as shown in Figure 14. The total module area is $34.9 \mathrm{~m}^{2}$, and the total PV system land area is $69.8 \mathrm{~m}^{2}$. The DS system requires system land area of 43.56 $\mathrm{m}^{2}$ with concentrator dish aperture area of $34.2 \mathrm{~m}^{2}$. Therefore, the DS system requires equivalent 18 PV modules, with $37.6 \%$ more land required for the PV system (Culligan \& Botkin, 2007).

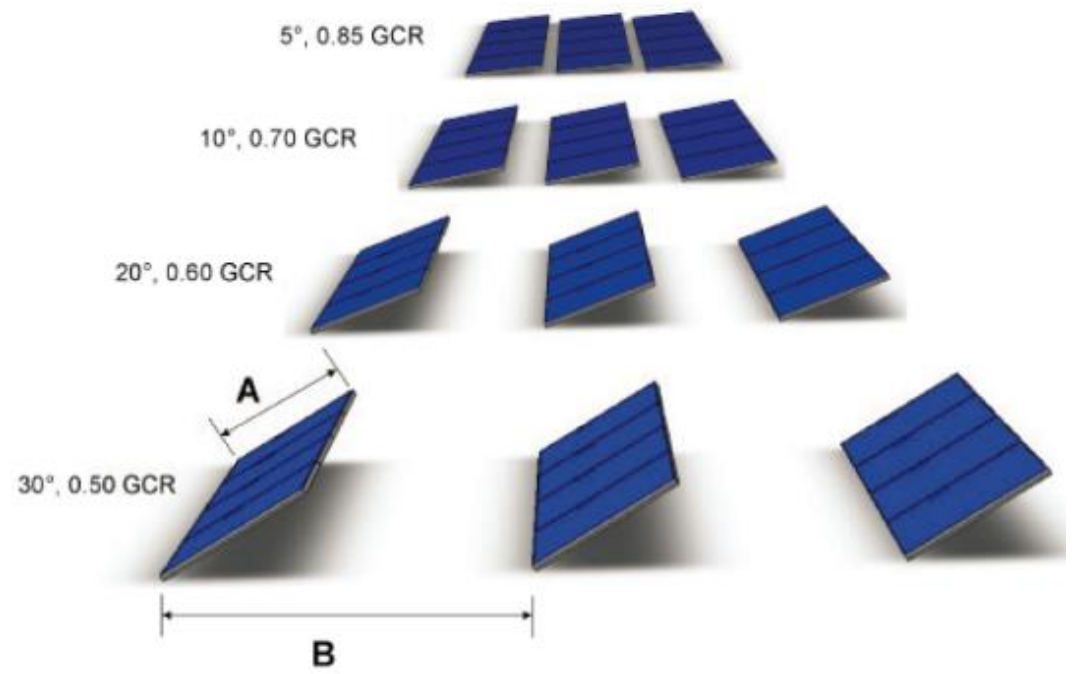

Figure 14 Different tilt angles and their corresponding GCR (Culligan \& Botkin, 2007)

The total land area occupied by the systems is calculated considering the spacing (GCR) between either the PV modules or the DS system units to overcome the shading effects. The results of this comparison show that the DS system needs less land area than the widely used PV systems.

Comparing the PV and DS systems by means of the Levelized Cost of Energy (LCOE) which is the measure of a power source that allows the comparison of different electricity generation methods on a consistent basis. LCOE is the economic assessment of the average total cost to implement and operate a power generation system over its lifetime divided by the total energy output of the system over that lifetime (Larchet et al., 2017).

There is no enough data for conducting this comparison in Egypt because of the absence of current DS projects in Egypt and the various parameters to calculate the value of LCOE. As a result, the comparison was done based on the data obtained from (Larchet et al., 2017) which compared between the LCOE value of the DS and PV systems in Morocco, which is a country located in the same region of Egypt and nearly has the same economical and geographical properties.

The results showed that the LCOE of DS system ranges from 77.7 \$/MWh to 91.8 \$/MWh depending on the production volume of the system, while the PV systems has a LCOE value of 65.4 \$/MWh (Larchet et al., 2017). 


\section{Conclusion}

In this research, the DS system components and models are studied to generate a comprehensive simulation model. The simulation was conducted to investigate the DS system performance in 21 different locations that cover Egypt. The yearly average output power of the engine ranges from $5.799 \mathrm{~kW}$ to $7.12 \mathrm{~kW}$ at El-Natroon and Fares zones respectively. Whereas, the engine efficiency ranges from $21.1 \%$ in El-Natroon to $24.1 \%$ in Fares. Generally, the engine performance does not show great variation across Egypt. A comparison was conducted between DS and PV systems at the same operating conditions. The DS technology has better efficiency and generates more power than PV technology. Results shows that the DS system requires $37.6 \%$ less land area than an equivalent PV system, while the PV systems is better in terms of levelized cost of energy (LCOE). The results obtained from the simulation provides promising indications for the use of dish Stirling engine systems in Egypt. Finally, future developments of DS system components with enhanced performance present a very promising opportunity for developing DS projects in Egypt.

\section{References}

Ahmadi, M. H., Ahmadi, M. A., \& Pourfayaz, F. (2017). Thermal models for analysis of performance of Stirling engine: A review. Renewable and Sustainable Energy Reviews, 68(February 2016), 168-184. https://doi.org/10.1016/j.rser.2016.09.033

Akella, A. K., Saini, R. P., \& Sharma, M. P. (2009). Social, economical and environmental impacts of renewable energy systems. Renewable Energy, 34(2), 390-396. https://doi.org/10.1016/j.renene.2008.05.002

Alaraby, S., Shufat, A., Kurt, E., Mohamed, K., Hadad, E., \& Hancerlioğulları, A. (2018). A numerical model for a Stirling engine A Numerical model for a Stirling engine JOURNAL OF ENERGY SYSTEMS. Journal of Energy Systems, 2(10), 1-12. https://doi.org/10.30521/jes.379164/0000-0002-2455-517X/0000-00023615-6926/0000-0002-0374-4350/0000-0001-7008-480X

Alarcón, J. A., Hortúa, J. E., \& G, A. L. (2013). Design and construction of a solar collector parabolic dish for rural zones in Colombia Diseño y construcción de un colector solar parabólico tipo disco para zonas rurales. Renuable Econmics, 7(14), 14-22. https://doi.org/10.18180/tecciencia.2013.14.2

Alexakis, A. (2013). CFD Modeling of Stirling Engines with Complex Design Topologies. University of Northumbria.

Bataineh, K., \& Taamneh, Y. (2017). Performance analysis of stand-alone solar dish Stirling system for electricity generation. International Journal of Heat and Technology, 35(3), 498-508. https://doi.org/10.18280/ijht.350306

Beltran, R., Velazquez, N., Espericueta, A. C., Sauceda, D., \& Perez, G. (2012). Mathematical model for the study and design of a solar dish collector with cavity receiver for its application in Stirling engines. Journal of Mechanical Science and Technology, 26(10), 3311-3321. https://doi.org/10.1007/s12206-012-08010

Berchowitz, D. M. (2016). A Phasor Description of the Stirling Cycle. In 
International Stirling Engine Conference (pp. 1-11).

Çinar, C. (2007). Thermodynamic analysis of an $\alpha$-type Stirling engine with variable phase angle. Journal of Mechanical Engineering Science, 221(8), 949-954. https://doi.org/10.1243/09544062JMES572

Culligan, M., \& Botkin, J. (2007). Impact of Tilt Angle on System Economics for Area Constrained Rooftops. San Jose, CA. Retrieved from sunpowercorp.com

Diver, R. B., Rawlinson, K. S., Goldberg, V., Andraka, C. E., Moss, T. A., \& Thomas, G. (2003). Status of The Advanced Dish Development System Project. In 2003 International Solar Energy Conference (pp. 15-18).

Egas, J., \& Clucas, D. M. (2018). Stirling Engine Configuration Selection. Energies (19961073), 11(3), 1-N.PAG. https://doi.org/10.3390/en11030584

El-Askary, H., Kosmopoulos, P., \& Kazadzis, S. (2018). The Solar Atlas of Egypt.

Ferreira, A. C. M., Teixeira, S. de F. C. F., Martins, L. A. de S. B., \& Nunes, M. J. L. (2014). Numerical Optimization and Economic Analysis in the Design of a Micro-CHP System with a Stirling engine and a Solar Collector. University of Minho.

Ferreira, A. C., Oliveira, R. F., Nunes, M. L., Martins, L. B., \& Teixeira, S. F. (2014). Modelling and Cost Estimation of Stirling Engine for CHP Applications. Proceedings of the 2014 International Conference on Power Systems, Energy, Environment, Energy, En, 21-29.

Ferreira, A. C., Teixeira, S., Teixeira, J. C., Nunes, M. L., \& Martins, L. B. (2012). Modeling a Stirling Engine for Cogeneration Applications. In ASME 2012 International Mechanical Engineering Congress and Exposition (pp. 361-369).

Fraser, P., \& Klein, P. S. a. (2008). Stirling Dish System Performance Prediction Model. Mechanical Engineering. University of Wisconsin-Madison.

Gholamalizadeh, E., \& Chung, J. D. (2017a). Design of the Collector of a Solar DishStirling System: A Case Study. IEEE Access, 5, 20754-20762. https://doi.org/10.1109/ACCESS.2017.2758354

Gholamalizadeh, E., \& Chung, J. D. (2017b). Exergy analysis of a pilot parabolic solar dish-stirling system. Entropy, 19(10), 1-12. https://doi.org/10.3390/e19100509

Hafez, A. Z., Soliman, A., El-Metwally, K. A., \& Ismail, I. M. (2016). Solar parabolic dish Stirling engine system design, simulation, and thermal analysis. Energy Conversion and Management, 126(August 2016), 60-75. https://doi.org/10.1016/j.enconman.2016.07.067

Harris, J. A., \& Lenz, T. G. (1985). Thermal performance of solar concentrator/cavity receiver systems. Solar Energy, 34(2), 135-142.

Hogan, R. E., Diver, R. B., \& Stine, W. B. (1990). Comparison of a Cavity Solar Receiver Numerical Model and Experimental Data. Journal of Solar Energy Engineering, 112(3), 183. https://doi.org/10.1115/1.2930478

Howard, D., \& Harley, R. G. (2010). Modeling of Dish-Stirling Solar Thermal Power Generation. In Proc. 2010 IEEE PES General Meeting, Minneapolis, Minnesota (pp. 1-7).

Howard, D., Harley, R., \& Venayagamoorthy, G. K. (2010). Modeling and Grid 
Integration of Large Dish - Stirling Solar Farm, 2010.

Johnson, B. (2018). Energy and Civilization: A History. Environmental History, 23(3), 658-659. https://doi.org/10.1093/envhis/emy036/4996458

Kalogirou, S. A. (2004). Solar thermal collectors and applications. Progress in Energy and Combustion Science (Vol. 30). https://doi.org/10.1016/j.pecs.2004.02.001

Karimi, R., Gheinani, T. T., \& Madadi Avargani, V. (2018). A detailed mathematical model for thermal performance analysis of a cylindrical cavity receiver in a solar parabolic dish collector system. Renewable Energy, 125, 768-782. https://doi.org/10.1016/j.renene.2018.03.015

Keck, T., Schiel, W., Reinalter, W., \& Heller, P. (2002). EuroDish - an innovative dish / Stirling system. In Solar Paces International Symposium on Concentrated Solar Power and Chemical Energy Technolgies (pp. 1-7).

Kongtragool, B., \& Wongwises, S. (2003). A review of solar-powered Stirling engines and low temperature differential Stirling engines. Renewable and Sustainable Energy Reviews, 7(2), 131-154. https://doi.org/10.1016/S13640321(02)00053-9

Larchet, K., Guédez, R., Topel, M., Gustavsson, L., Machirant, A., Hedlund, M. L., \& Laumert, B. (2017). Enhancing economic competiveness of dish Stirling technology through production volume and localization: Case study for Morocco. AIP Conference $\quad 1850$. https://doi.org/10.1063/1.4984406

Lovegrove, K., \& Stein, W. (2012). Concentrating Solar Power Technology: Principles, developments and applications. Concentrating Solar Power Technology. https://doi.org/10.1533/9780857096173.3.577

Mancini, T., Heller, P., Butler, B., Osborn, B., Schiel, W., Goldberg, V., ... Moreno, J. (2003). Dish-Stirling Systems: An Overview of Development and Status. Journal of Solar Energy Engineering, 125(2), 125-135. https://doi.org/10.1115/1.1562634

Mansiri, K., Sukchai, S., \& Sirisamphanwong, C. (2014). Investigations to conduct a study about possibilities to use small scale solar dish Stirling engine system in Thailand. Energy Procedia, 56(C), 367-377. https://doi.org/10.1016/j.egypro.2014.07.169

Nepveu, F., Ferriere, A., \& Bataille, F. (2009). Thermal model of a dish/Stirling systems. Solar Energy, $\quad 83(1), \quad 81-89$. https://doi.org/10.1016/j.solener.2008.07.008

Praene, J.-P., Radanielina, H., \& To, T. R. (2015). Dish Stirling system potential assessment for eight main sites in Madagascar. Journal of Heat and Mass Transfer, 13(1), 119-141.

Rabl, A. (1976). Comparison of solar concentrators. Solar Energy, 18(2), 93-111. https://doi.org/10.1016/0038-092X(76)90043-8

Racharla, S., \& Rajan, K. (2017). Solar tracking system - a review. International Journal of Sustainable Engineering, 10(2), 72-81. https://doi.org/10.1080/19397038.2016.1267816 
Reinalter, W., Ulmer, S., Heller, P., Rauch, T., Gineste, J.-M., Ferriere, A., \& Nepveu, F. (2008). Detailed Performance Analysis of a $10 \mathrm{~kW}$ DishStirling System. Journal of Solar Energy Engineering, 130(1), 011013. https://doi.org/10.1115/1.2807191

Rogdakis, E. D., Antonakos, G. D., \& Koronaki, I. P. (2012). Thermodynamic analysis and experimental investigation of a Solo V161 Stirling cogeneration unit. Energy, 45(1), 503-511. https://doi.org/10.1016/j.energy.2012.03.012

Saša Pavlović, Velimir Stefanović, Darko Vasiljević, \& Emina Petrović. (2015). Optical Design of a Solar Parabolic Concentrating Collector Based on Trapezoidal Reflective Petals. Journal of Energy and Power Engineering, 9(8). https://doi.org/10.17265/1934-8975/2015.08.004

Shazly, J. H., Hafez, A. Z., El-Shenawy, E. T., \& Eteiba, M. B. (2014). Simulation, design and thermal analysis of a solar Stirling engine using MATLAB. Energy Conversion and Management, 79, 626-639. https://doi.org/10.1016/j.enconman.2014.01.001

Timoumi, Y., Tlili, I., \& Ben Nasrallah, S. (2008). Design and performance optimization of GPU-3 Stirling engines. Energy, 33(7), 1100-1114. https://doi.org/10.1016/j.energy.2008.02.005

Tlili, I., \& Musmar, S. A. (2013). Thermodynamic evaluation of a second order simulation for Yoke Ross Stirling engine. Energy Conversion and Management, 68, 149-160. https://doi.org/10.1016/j.enconman.2013.01.005

Tlili, I., Timoumi, Y., \& Nasrallah, S. Ben. (2008). Analysis and design consideration of mean temperature differential Stirling engine for solar application. Renewable Energy, 33(8), 1911-1921. https://doi.org/10.1016/j.renene.2007.09.024

Urieli, I., \& Berchowitz, D. M. (1984). Stirling cycle engine analysis. A. Hilger.

Wagner, A. (2008). Calculations and experiments on Gamma-type Stirling engines. University of Wales. Retrieved from http://orca.cf.ac.uk/54057/1/U585566.pdf

Wies, R. W., Johnson, R. A., \& Agrawal, A. N. (2012). Energy-Efficient Standalone Fossil-Fuel Based Hybrid Power Systems Employing Renewable Energy Sources. In Fossil Fuel and the Environment, Dr. Shahriar Khan (pp. 121-142). Retrieved from http://www.intechopen.com/books/fossil-fuel-andtheenvironment/\%0Aenergy-efficient-standalone-fossil-fuel-based-micro-gridsystems-with-renewable-energy-andsmart-\%0Agri

William B. Stine and Richard B. Diver. (1994). A Compendium of Solar Dish/Stirling Technology, 116. https://doi.org/SAND93-7026 UC-236

Yan, J., Peng, Y. D., Cheng, Z. R., Liu, F. M., \& Tang, X. H. (2017). Design and implementation of a $38 \mathrm{~kW}$ dish- Stirling concentrated solar power system Design and implementation of a $38 \mathrm{~kW}$ dish-Stirling concentrated solar power system. IOP Conf. Series: Earth and Environmental Science, 93, 1-14. 